\title{
TERRAIN ANALYSIS IN THE COURSE CURRICULA OF THE SOUTH AFRICAN ARMY ENGINEER CORPS
}

\author{
KP Lodi, HAP Smit and GK Ayirebi \\ Stellenbosch University ${ }^{I}$
}

Engineer officers are expected to be terrain experts. [...] My personal frustrations and shortcomings point to a training deficiency that must be addressed before we can adequately label ourselves as both terrain experts and topographic officers. ${ }^{1}$

\begin{abstract}
The research reported here examined the engineer occupational course curricula presented by the South African Army School of Engineers. Methodology involved examination of all enabling learning objectives for the Corps Training Course (701 ENGR 006), the Troop Officers Course (701 ENGR 103), the Troop Commanders Course (701 ENGR 16) and the Squadron Commanders Course (701 ENGR 17). The research determined the number of learning objectives dedicated to terrain analysis and whether those learning objectives were linked to an assessment to determine competency levels for terrain analysis. The study used content analysis to determine the presence of terrain analysis content in the course curricula and to make recommendations. Data have been collected from analysis of the first four occupational course curricula presented to officers of the Engineer Corps as mentioned above, books, army field manuals and occasional papers. Recommendations are that the learning objectives dedicated to terrain analysis should be expanded and better focused and that assessment instruments capable of measuring competency in terrain analysis should be created and/or improved. An additional recommendation is that exercises are needed during the occupational courses that require officers to assimilate the effect of terrain on operations in order to improve officers' terrain analysis competencies. This will serve as an important assessment instrument that will improve development of officers' skills and earn

Scientia Militaria, South African Journal of Military Studies, Vol 42, Nr 1, 2014, pp. 102-121. doi : $10.5787 / 42-1-1083$

them experience, not just grades.

\section{Introduction}

Terrain is a permanent and important aspect of all military operations. The military study of terrain is called 'terrain
\end{abstract}

\footnotetext{
${ }^{1}$ The opinions, conclusions and recommendations expressed in the article are that of the authors and not necessarily those of the SA Army Engineer Formation.
} 
analysis' and it is the responsibility of military engineers to maximise its effect for the tactical, operational and strategic operations of the army. Engineer officers are the commanders' terrain experts, armed with distinct skills and knowledge. More than two thousand years ago, the importance of terrain analysis by military leaders was recognised. Sun Tzu advocated the use of local guides to take advantage of the face of the country. ${ }^{2}$ Terrain deals with all the physical, cultural and geographical features of a given area. ${ }^{3}$ The study of terrain has been an enduring combat responsibility for army engineers around the world and throughout history. Military terrain analysis is a fundamental requirement for successful planning of all types of military operations, regardless of whether this entails armed conflict or military operations other than war. Raw information about terrain does not equate to terrain analysis; such information has to be applied in the relevant context.

Military operations occur at three levels: tactical, operational and strategic. ${ }^{4}$ Although terrain analysis can and should be done at all three levels, this article will focus on the tactical level, and as such, most of the examples cited in this article will refer to the tactical level of military operations.

The South African Army Engineer Corps states that it is responsible for ensuring that terrain is utilised and employed to the benefit of the South African Army. ${ }^{5}$ Military terrain analysis is a learnt skill, best developed by extensive training and experience. The terrain expert, often faced with severe time constraints, must be able to decide which of many competing factors should be given priority in the analysis of any specific context. ${ }^{6}$

\section{Definition of an engineer terrain expert}

Colonel Edward Arnold, interim director of the U.S. Training and Doctrine Command (TRADOC) Program Integration Office - Terrain Digitisation, at Fort Leonard Wood in 1997, coined the label 'terrain visualisation expert' in the article "Being a terrain visualisation expert". In this article, Colonel Arnold described the importance of terrain visualisation for the manoeuvre commander and how engineer officers and terrain warrant officers should have the technical proficiency in creating digital terrain products to aid in terrain analysis. ${ }^{7}$

The past five United States Army Engineers School commandants have also promoted the idea that engineers are the army's terrain experts. Major General Anders Aadland stated:

Geospatial engineering is the development, dissemination, and analysis of terrain information that is accurately referenced to precise locations on the earth's surface. Although this is a new terminology (replacing topography), the emphasis is still on engineers being the terrain experts for the manoeuvre commander. [...] Engineer leaders must know how to exploit this information. ${ }^{8}$

The US Army Field Manuals, as a whole, only mention engineer officers as terrain experts in passing as shown in the following excerpts: 
- $\quad$ FM 5-10, Combat Engineer Platoon, simply states, "The platoon leader must advise the manoeuvre commander on the military aspects of the terrain since he is the terrain expert."

- $\quad$ FM 5-100, Engineer Operations, states, "The engineer is the terrain expert. He must work closely with the S2 to determine advantages and disadvantages the terrain gives the attacking force." 10

- FM 17-95, Cavalry Operations, states, "The regimental engineer is the terrain expert."11

- $\quad$ FM 90-13, River Crossing Operations, states, "Engineers analyse the terrain to determine the manoeuvre potential, ways to reduce natural and enemy obstacles, and how they can deny freedom of manoeuvre to the enemy by enhancing the inherent obstacle value of the terrain. [...] The engineer is the terrain expert."12

- $\quad$ FM 3-34.230, Topographic Operations, describes the engineer officer's geospatial role as that of terrain visualisation expert. This expert "assists the commander in visualising the terrain, identifying and understanding terrain aspects for exploitation by friendly and enemy forces, and providing subjective evaluation of the terrain's physical attributes and physical capabilities of vehicles, equipment and people". ${ }^{13}$

Though none of these references provides a clear definition of a terrain expert, they all indicate several important tasks for the terrain expert. First, the engineer officer must be able to use and integrate geospatial tools into his or her analysis of terrain. Second, the terrain expert must be able to generate, obtain and/or use geospatial products, such as overlays. Third, he or she should have a close working relationship with the military intelligence staff and the engineer terrain warrant officer. For the purposes of this study, the following working definition of a terrain expert was formulated:

A terrain expert can be defined as one who is able to integrate the physical and human elements of the area of operation to provide the commander with a clear understanding of the nature of the operational area so that informed decisions can be made.

The expert understands the limitations and capabilities of geospatial information and can integrate them into the appropriate tactical language and processes. Engineer doctrine states that the engineer officer is the terrain expert. ${ }^{14}$

The facts stated above support the fact that engineers are the mobility and counter-mobility experts of the army. Engineers do other things too, but their role as members of the army largely comprises mobility and counter-mobility operations. ${ }^{15}$ Engineers cannot effectively fulfil either of these functions without a comprehensive understanding of how terrain affects the movement of friendly and enemy forces. In reality, engineers practise terrain analysis expertise every day, generally without 
giving it a second thought. Every time advice is given to a commander, whether on the correct placement of an obstacle to achieve the desired effect, or on the shifting of a battle position to achieve better engagement area coverage or to gain increased survivability, engineers are using terrain analysis skills to assist the commander in understanding terrain effects. ${ }^{16}$ In support of the offence, engineers help define where the enemy might set defences based on the limiting effects of the terrain, or where they might place obstacles to create advantage from the opportunities afforded by the terrain. Engineers do this throughout their careers at every level of command and staff.

\section{Military dimensions of terrain}

Commanders make decisions to fit the military aspects of terrain, and terrain analysts and decision-makers should pay attention to these military aspects. Military aspects of terrain are formulated as OCOKA, implying information on observation and field of fire, cover and concealment, obstacles, key terrain and avenue of approach. ${ }^{17}$ Observation and field of fire are important factors for military decisions. Field of fire supplies horizontal line of sight for direct-fire weapons and radars. Observation areas are important for ground surveillance. Vegetation with qualified density or a hill point might serve as points for observation and field of fire. Cover protection from enemy fire is a vital part of any military operation. Examples of such cover are rocks, river banks, vegetation, quarries, walls and buildings. Concealment is protection from observation. This information is important for judging where the enemy might be located. It is especially important in areas where guerrilla forces might be operating because it helps the commander predict attacks. ${ }^{18}$ Similarly, during disaster relief operations, peacekeeping operations, etc. it is important for the commander to have a thorough knowledge of the terrain to make informed decisions. Concealment may be provided by woods, underbrush, snowdrifts, tall grass, cultivated vegetation, roof coverage, or any other feature that denies observation.

An obstacle is any natural or man-made obstacle, such as built-up areas or cemeteries. The key terrain is that part of the operation zone which affects the operation for both the enemy and friendly forces. The side which captures the key terrain claims an advantage over the other side. Therefore, key terrain is important both during the planning and implementation stages of the operation. Examples are bridges, urban areas and key military installations. Cross-country movement information is sometimes referred to as an avenue-of-approach map because it shows the best routes for various vehicles and areas which cannot be crossed. Crosscountry movement information includes slope (surface configuration), vegetation and soils (surface materials) information, the base topographic map, and aerial photographs. 


\section{Officer education and training in the military}

Military organisations rely on education and training to prepare individuals and groups to perform extremely difficult tasks at high levels of proficiency under stressful conditions. Both education and training are needed: training to provide the knowledge and skills needed to perform military tasks and jobs, and education to help military personnel at all levels decide when and how to apply the knowledge and skills that they acquire through training. ${ }^{19}$ The army educates its officers by three methods: institutional training, ${ }^{20}$ operational assignments and self-development. ${ }^{21}$ Education is distinct from training in that "Education implies the transmission of knowledge and skills required for effectiveness", as opposed to training which is used "to perform specific functions, tasks, or missions". ${ }^{22}$ However, both are essential to develop a professional military officer capable of making informed and reasonable decisions to support a commander's intent.

During the last couple of decades, a concerted effort was made to match leader knowledge and experience to the appropriate level of responsibility. A robust leader and training development programme emerged in the late 1970s, which provided leaders with a progressive and sequential educational system to prepare them for different levels of responsibility. ${ }^{23}$ Today, however, there is evidence of changes occurring in areas which, if left unattended, may dramatically alter the relevance and the effectiveness of the current system for the army's leader development, and even more profoundly in the future.

The first change is a shift in leader focus from information gathering to rapid learning. The most direct implication for leader development is an increasing need to focus on how to think as opposed to what to think, and to accelerate the development of rapid learning skills. ${ }^{24}$

The second area of change is a shift from a linear and compartmental relationship between the tactical, operational and strategic levels of war to an overlapping and inter-connected relationship. The most direct implication for leader development is the need to purposefully nurture operational or strategic know-how early in professional development, as opposed to waiting until the twentieth year of service. The Information Age clearly demands redefining leader thinking requirements.

The army must shift its focus from teaching what to think, to how to think, and should adopt rapid learning techniques to exploit the knowledge advantage. It must also shift towards more rapid experiential growth in order to foster a wisdom advantage.

The literature suggests that the commander's ability to visualise the battlefield is both a science and an art. ${ }^{25}$ Military theory supports the idea that the commander's ability to visualise the terrain and its impact on operations is a critical skill in planning and conducting all types of military operations. ${ }^{26}$ The commander's primary tool for analysing and assessing terrain when planning and conducting 
operations is the process of intelligence preparation of the battlefield. Both theory and research suggest that terrain visualisation and terrain analysis are associated with experience on the ground, with a map, solving problems dealing with space, direction, distance and location.

Given the significance of developing the commander's terrain analysis and terrain visualisation skills, to which extent are these skills emphasised in the formal development of officers as terrain analysts? More interestingly, does emphasis on developing these skills exist at all? The current research intended to answer these questions.

\section{Research aim and objectives}

The aim of the current research was to conduct a review of terrain analysis considerations in the officers' occupational course curricula of the South African Engineering Corps - from its Corps Training Course up to the Squadron Commanders' Course. This review serves as an evaluation of whether officers in the South African Engineer Corps received the required terrain analysis knowledge and skills throughout their formal training and development as officers.

The primary research question was: Do the curricula for engineer officers' occupational courses at the South African School of Engineers contribute to the army's goal of developing leaders who are competent in terrain analysis? In order to answer this primary question, the following secondary questions needed to be answered:

1. Which curriculum does the school currently present that includes terrain analysis content?

2. Which learning units mention terrain analysis content as a part of the lesson plans?

3. Where in the learning units is terrain analysis content mentioned?

4. Is terrain analysis content a learning objective for the lessons in which it appears?

5. Where terrain analysis content is a learning objective, is this learning assessed?

This study experienced several limitations which affected the conclusion of its findings. The first limitation was that the researchers assumed that the military standard of training was ensured. A second limitation was the curricula selected. Only the curricula of the first four courses of the South African Engineer Corps for officers were used for the study, which limited the reliability of the findings. The researchers chose to use only the first four courses because these were the only resident courses found at the School of Engineers, their curricula were easy to access, and these were the main courses that had to lay the foundation for officers in 
the Engineering Corps. Thus analysis of curricula from level one to four had to give clarity on the competence of engineer officers in terrain analysis.

The third limitation of the study was that it only measured one aspect of officers' training at particular points in their career. The research did not account for the operational experience of officers and the training they received during terrain analysis in this manner. Combat engineer officers develop terrain analysis skills during many of the exercises they conduct in the field; yet, this level of development is not measured or accounted for. Finally, literature regarding terrain analysis education in the military was limited and sometimes outdated.

\section{Research design}

The data in the research were collected by means of a literature review and a content analysis of the first four officers' occupational course curricula, namely: Corps Training Course (701 ENGR 006), ${ }^{27}$ the Troop Officers Course (701 ENGR $103),{ }^{28}$ the Troop Commanders Course (701 ENGR 16), ${ }^{29}$ and the Squadron Commanders Course (701 ENGR 17) ${ }^{30}$ presented by the South African Army School of Engineers. Figure 1 shows a schematic representation of the research design for this study.

By examining and analysing the content of the course curricula, it was possible to evaluate whether officers in the Engineer Corps received the necessary terrain analysis knowledge throughout their formal training. The next section describes the methodology used to achieve the aim of this research.

\section{Content analysis as a methodology to analyse text}

Content analysis is a technique for gathering and analysing the content of text. In the framework of the current study, this entailed the analysis of the content of the above-mentioned course curricula. This methodology had to answer the research questions and offer recommendations. Before a detailed data collection and analysis can be given, content analysis as a methodology must however be explained.

Content analysis has a long history in research, dating back to the eighteenth century in Scandinavia. ${ }^{31}$ In the United States, content analysis was first used as an analytic technique at the beginning of the twentieth century. ${ }^{32}$ Initially, researchers used content analysis as either a qualitative or quantitative method in their studies. ${ }^{33}$ Later, content analysis was used primarily as a quantitative research method, with text data coded into explicit categories and then described using statistics. This approach is sometimes referred to as the 'quantitative analysis of qualitative data'. ${ }^{34}$ More recently, the potential of content analysis as a method of qualitative analysis has been recognised, leading to its increased application and popularity. ${ }^{35}$ 


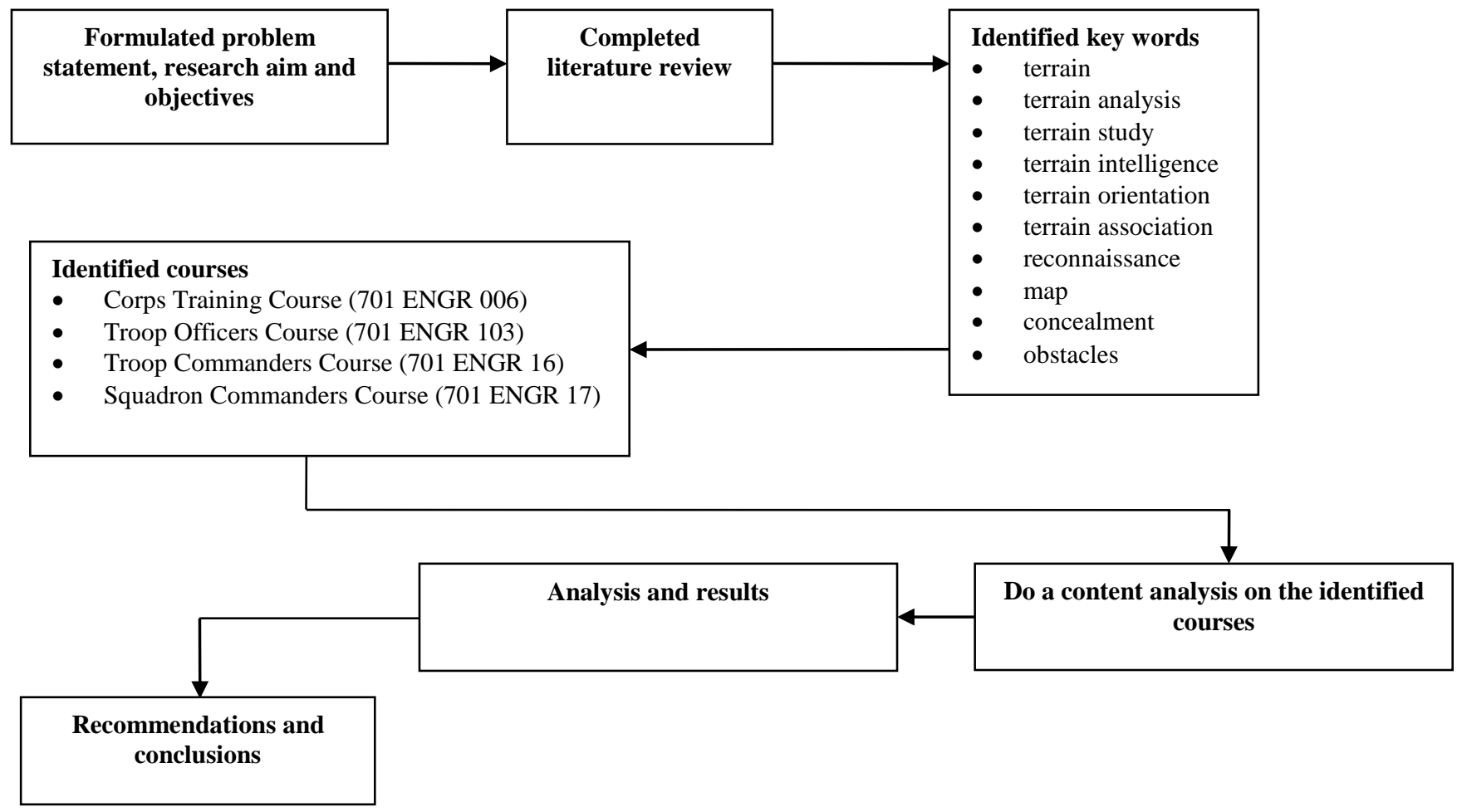

Figure 1: A schematic representation of the research design for the study 
Qualitative content analysis goes beyond merely counting words, but rather examines language intensely for the purpose of classifying large amounts of text into an efficient number of categories that represent similar meanings. ${ }^{36}$ These categories can represent either explicit communication or inferred communication. The goal of content analysis is "to provide knowledge and understanding of the phenomenon under study". ${ }^{37}$ Hsieh and Shannon define qualitative content analysis as "A research method for the subjective interpretation of the content of text data through the systematic classification process of coding and identifying themes or patterns." 38

The specific type of content analysis approach chosen by a researcher varies according to the theoretical and substantive interests of the researcher and the problem being studied. ${ }^{39}$ Although this flexibility makes content analysis useful for a variety of researchers, the lack of a firm definition and procedures potentially limits the application of content analysis. ${ }^{40}$

Content analysis is not a single method, but currently shows three distinct approaches: conventional, directed and summative. However, all of these approaches are used to deduce meaning from the content of text data. ${ }^{41}$ Table 1 shows major coding differences among the three approaches of content analysis. For the purpose of this research, summative content analysis was used.

Table 1: Coding differences among three approaches of content analysis ${ }^{42}$

\begin{tabular}{|l|l|l|l|}
\hline $\begin{array}{c}\text { Type of content } \\
\text { analysis }\end{array}$ & $\begin{array}{c}\text { Study starts } \\
\text { with }\end{array}$ & $\begin{array}{l}\text { Timing of defining } \\
\text { codes or keywords }\end{array}$ & $\begin{array}{c}\text { Source of codes or } \\
\text { keywords }\end{array}$ \\
\hline $\begin{array}{l}\text { Conventional } \\
\text { content analysis }\end{array}$ & Observation & $\begin{array}{l}\text { Codes are defined } \\
\text { during data analysis }\end{array}$ & $\begin{array}{l}\text { Codes are derived } \\
\text { from data }\end{array}$ \\
\hline $\begin{array}{l}\text { Directed content } \\
\text { analysis }\end{array}$ & Theory & $\begin{array}{l}\text { Codes are defined } \\
\text { before and during } \\
\text { data analysis }\end{array}$ & $\begin{array}{l}\text { Codes are derived } \\
\text { from theory or } \\
\text { relevant research } \\
\text { findings }\end{array}$ \\
\hline $\begin{array}{l}\text { Summative } \\
\text { content analysis }\end{array}$ & Keywords & $\begin{array}{l}\text { Keywords are } \\
\text { identified before } \\
\text { and during data } \\
\text { analysis }\end{array}$ & $\begin{array}{l}\text { Keywords are derived } \\
\text { from interest of } \\
\text { researcher or review } \\
\text { of literature }\end{array}$ \\
\hline
\end{tabular}

\section{Data collection and analysis}

The first step in the current study was to sort the content of the research into categories and themes. The four overarching categories in this research were the four major courses presented to officers at the South African Army School of Engineers, namely the Corps Training Course (701 ENGR 006), ${ }^{43}$ the Troop Officers Course (701 ENGR 103), ${ }^{44}$ the Troop Commanders Course (701 ENGR $16)^{45}$ and the Squadron Commanders Course (701 ENGR 17). ${ }^{46}$ These categories 
(courses) were sub-divided into smaller areas of curriculum content or themes, namely learning units, specific outcomes and learning objectives. 'Learning units', 'specific outcomes' and 'learning objectives' are the terms used by the South African Army School of Engineers to describe and manage a particular course of study. A 'learning unit' is a specific, manageable amount of curriculum content consisting of several specific outcomes. A 'specific outcome' is a sub-set of a learning unit. Each specific outcome consists of several 'learning objectives'. The specific outcomes thus form a single, continuous session of instruction supporting a learning unit.

Eight learning units of instruction made up the Corps Training Course (701 ENGR 006). This learning programme was designed to equip the field sapper with the general military engineering skills and knowledge to obtain the main objective of engineering, namely survivability of own forces, general engineer tasks and denial of enemy mobility. This learning programme was presented to members of the South African Engineer Corps, with the substantive rank of sapper. The Corps Training Course was the foundation course for all engineer officers. ${ }^{47}$

Seventeen learning units of instruction made up the Troop Officers Course (701 ENGR 103). This learning programme was designed to train South African Engineer Corps (SAEC) combat engineers who had been selected by the Engineer Formation Officers Selection Board as well as the SA Army Officers Selection Board for officer training at the SAEC. This training had to ensure that these combat engineers could be utilised in posts as troop officers in the Field Engineer Regiment, and, during operational conditions, within the Field Squadron. On successful completion of the learning programme, the learner would have been able to plan and execute field engineer tasks, such as terrain analysis, at sub-unit or squadron level. The learner would have been able to function as a troop officer and to assist the troop commander of the SAEC at sub-sub-unit level. ${ }^{48}$

Fourteen learning units of instruction made up the Troop Commanders Course (701 ENGR 16). This learning sub-programme was designed as a part of the training programme for all SAEC officers with the rank of lieutenant in the disciplines required for them to act as troop commanders in the SAEC. The members were required to have completed the SAEC Troop Officers Course successfully in order to be accepted for this course. Upon successful completion of this learning programme, the learner would have been able to plan and execute all combat engineer tasks and to gather information during reconnaissance as part of the responsibility of troop commander within the engineer squadron. The learner would have been equipped to act as an $\mathrm{SO} 3$ engineer and to function in a compartment of a formation. $^{49}$

Six learning units of instruction made up the Squadron Commanders Course (701 ENGR 17). This learning programme was designed to train SAEC officers with the rank of captain. The aim of this programme was to ensure that SAEC captains could be utilised in posts as SAEC squadron commanders in the Field Engineer Regiment, and to prepare them for the integrated Sub-Unit 
Commanders Course. This learning programme was presented to all SAEC officers with the rank of captain. The members were required to have completed the SAEC Troop Officers Course, the advanced bridge-building course and the equipment orientation course successfully in order to be accepted for this course. ${ }^{50}$ Upon successful completion of this learning programme, the learner would have been able to act as a Field Section Leader in the Field Engineer Regiment during operations. ${ }^{51}$

During the content analysis, the researchers searched for terrain analysis content in the lesson plans of the officers' occupational course curricula. Manual analysis was used to scan each learning unit for keywords relevant to terrain analysis. Each learning unit was searched for the ten identified keywords: 'terrain', 'terrain analysis', 'terrain study', 'terrain intelligence', 'terrain orientation', 'terrain association', 'reconnaissance', 'map', 'concealment', and 'obstacles'. Table 2 shows terrain analysis-related keywords selected for this research and their definitions. These words were selected from the literature review and other sources relating to terrain analysis.

The words are relevant because they represent the tasks for terrain analysis as described in the literature review. When a keyword was found in a learning unit, that learning unit was analysed further to determine whether the terrain analysis content in the learning unit was significant. 'Significance' in this research meant that terrain analysis-related content (one or more of the identified keywords) was part of the learning objectives in the learning unit, and that the learning objective was assessed. The term 'potentially significant' was used to refer to the keywords that were identified in the learning units at first glance, before determination of significance (that is, before checking whether the particular keyword was part of the learning objectives or an assessment for that particular learning unit). The amount of terrain analysis-relevant content in the curricula was also calculated according to the number of learning units that mentioned terrain analysis keywords in their content.

Once the analysis of curricula was completed, a final determination was made as to whether the terrain analysis content found in the South African Army School of Engineers curricula contributed to the stated goal of the SA Army to develop leaders who were competent in terrain analysis.

To answer the primary research question, the learning units in which terrain analysis was identified as part of the learning objectives as well as in which the learners were assessed were recorded as having made a contribution to the SA Army's goal of developing leaders who were competent in terrain analysis.

To answer the first of the secondary research questions, the following steps were taken to review all the lessons presented during the course.

Only the first four officers' occupational course curricula of the South African Engineer Corps were obtained in hard copy format from the School of 
Table 2: Terrain analysis-related keywords selected for the study

\begin{tabular}{|c|c|c|}
\hline No & Keywords & Definitions \\
\hline 1 & Concealment & Protection from observation only. ${ }^{52}$ \\
\hline 2 & Map & $\begin{array}{l}\text { Graphic representation, usually on a plane surface } \\
\text { and with an established scale of natural and } \\
\text { artificial features on the surface of a part or the } \\
\text { whole of the earth or other planetary body. Features } \\
\text { are positioned relative to a coordinate reference } \\
\text { system. }\end{array}$ \\
\hline 3 & Obstacles & $\begin{array}{l}\text { Any natural or artificial obstacles stopping or } \\
\text { diverting movements of materials and troops. }\end{array}$ \\
\hline 4 & Reconnaissance & $\begin{array}{l}\text { Mission undertaken to obtain, by visual observation } \\
\text { or other detection methods, information about the } \\
\text { activities and resources of an enemy or potential } \\
\text { enemy, or to secure data concerning the } \\
\text { meteorological, hydrographic, or geographic } \\
\text { characteristics of a particular area. } 55\end{array}$ \\
\hline 5 & Terrain & $\begin{array}{l}\text { A tract of country considered with regard to its } \\
\text { natural features, configuration; in military use } \\
\text { especially as affecting its tactical advantages, } \\
\text { fitness for maneuvering, etc. }\end{array}$ \\
\hline 6 & Terrain analysis & $\begin{array}{l}\text { The collection, analysis, evaluation, and } \\
\text { interpretation of geographic information on the } \\
\text { natural and man-made features of the terrain, } \\
\text { combined with other relevant factors, to predict the } \\
\text { effect of the terrain on military operations. }\end{array}$ \\
\hline 7 & $\begin{array}{l}\text { Terrain } \\
\text { association }\end{array}$ & $\begin{array}{l}\text { The process of continuously identifying features on } \\
\text { the ground and associating them with their graphic } \\
\text { representations on a map. }\end{array}$ \\
\hline 8 & $\begin{array}{l}\text { Terrain } \\
\text { intelligence }\end{array}$ & $\begin{array}{l}\text { Processed information on the military significance } \\
\text { and implications of natural and man-made } \\
\text { characteristics of an area. }\end{array}$ \\
\hline 9 & $\begin{array}{l}\text { Terrain } \\
\text { orientation }\end{array}$ & $\begin{array}{l}\text { The act or process of orienting location or position } \\
\text { relative to the points of the compass on an area. }\end{array}$ \\
\hline 10 & Terrain study & $\begin{array}{l}\text { Analysis and interpretation of natural and man- } \\
\text { made features of an area, their effects on military } \\
\text { operations and the effect of weather and climate on } \\
\text { these features. }\end{array}$ \\
\hline
\end{tabular}


engineers. The lesson plan review and analysis process proceeded by scanning each curriculum learning unit for instruction manually for terrain analysis-relevant keywords. This process revealed which learning units mentioned terrain analysis.

To answer the question of where in the learning unit terrain analysis was mentioned, the research method was designed to scan and find keywords manually in one of the two parts of the learning units described earlier, namely for facilitators and learners, and for facilitators only. Discovery of content through manual scanning listed all specific outcomes by title, highlighted those that mentioned terrain analysis-related keywords, and specified the location of identified terrain analysis keywords in the learning unit. This search thus revealed which learning units specifically addressed terrain analysis as part of the learning objective. If a learning unit was found to have terrain analysis keywords as part of a learning objective, the assessment portion of that lesson was examined to determine whether the terrain analysis learning objective was assessed. If the learning objective was assessed, this was deemed a significant finding.

Significant findings were considered to contribute to the SA Army's goal of developing leaders who were competent in terrain analysis, as this learning objective was not merely indicated in the lesson plan, but was assessed; making sure that learners had mastered the content.

After this process, recommendations for future considerations on terrain analysis in the occupational course curricula presented to officers of the SAEC were made. The analysis and results of this methodology are presented in the next section.

\section{Research analysis and findings}

Table 3 shows the amount of terrain analysis content found in the curricula. The content found was divided into potentially significant and significant content as per research definition.

As defined earlier, 'significance' in this research meant that terrain analysis-related content was part of the learning objectives in the learning unit, and that the learning objective was assessed. The term 'potentially significant' was used to refer to the keywords for terrain analysis that were identified in the learning units at first glance, before determination of significance (before checking if the particular keyword was part of learning objectives or an assessment for that particular learning unit).

Firstly, potentially significant keywords for terrain analysis appeared in two out of eight learning units in the Corps Training Course (701 ENGR 006) and constituted approximately 25 per cent of the curriculum. Of the 25 per cent of potentially significant content, only 12,5 per cent mentioned terrain analysis-related content in the learning objectives and it was assessed, thus making it significant to the research. The Corps Training Course served as the most basic course that laid the foundation for the other three, therefore its lack of content with regard to terrain analysis showed that learners received a minimal amount of terrain analysis 
knowledge and skills at the starting point of their career in the Engineer Corps. Thus, there was a need for a deepening of content in terrain analysis in order to equip learners with much-needed knowledge and skills at the early stages.

Table 3: Amount of terrain analysis content in the curricula

\begin{tabular}{|c|c|c|c|c|}
\hline Course name & Potentially significant content & \multicolumn{2}{|c|}{ Significant content } \\
\hline & $\begin{array}{c}\text { Learning } \\
\text { unit } \\
\text { numbers }\end{array}$ & Percentage & $\begin{array}{c}\text { Learning } \\
\text { unit numbers }\end{array}$ & Percentage \\
\hline $\begin{array}{c}\text { Corps Training } \\
\text { (701 ENGR }\end{array}$ & 2 out of 8 & 25 & 1 out of 8 & 12,5 \\
\hline $\begin{array}{c}\text { Troop Officers } \\
\text { (701 ENGR } \\
\text { 103) }\end{array}$ & 7 out of 17 & 42 & 7 out of 17 & 42 \\
\hline $\begin{array}{c}\text { Troop } \\
\text { Commanders } \\
\text { (710 ENGR 16) }\end{array}$ & 3 out of 14 & 21 & 3 out of 14 & 21 \\
\hline $\begin{array}{c}\text { Squadron } \\
\text { Commanders } \\
\text { (701 ENGR 17) }\end{array}$ & 3 out of 6 & 50 & 3 out of 6 & 50 \\
\hline
\end{tabular}

Secondly, potentially significant keywords for terrain analysis appeared in seven out of seventeen learning units in the Troop Officers Course (701 ENGR 103) and constituted approximately 42 per cent of the curriculum. All of the 42 per cent of potentially significant content mentioned terrain analysis-related content in the learning objectives and it was assessed, thus making it significant to the research. The lesson plan of the Troop Officers Course was mainly dedicated to terrain orientation, which was of great importance in the Engineer Corps. This seemed by far the best course in terms of how it considered terrain analysis in its lessons.

Thirdly, potentially significant keywords for terrain analysis appeared in three out of fourteen learning units in the Troop Commanders Course (701 ENGR 16) and constituted approximately 21 per cent of the curriculum. All of the 21 per cent of potentially significant content mentioned terrain analysis-related content in the learning objectives and it was assessed, thus making it significant to the research. This was the lowest rating course in terms of terrain analysis content when compared to the other three. This is critically important information, because the commander should have terrain analysis skills and knowledge in order to be able to visualise the operational terrain. Thus, if a commander is not exposed to greater 
depth and width of terrain analysis education than was evident in the Troop Commanders Course at the time of the study, there is risk on the battlefield, and during other types of military operations.

Lastly, potentially significant keywords for terrain analysis appeared in three out of six learning units in the Squadron Commanders Course (701 ENGR 17) and constituted approximately 50 per cent of the curriculum. All of the 50 per cent of potentially significant content mentioned terrain analysis-related content in the learning objectives and it was assessed, thus making it significant to the research. The course itself proved to be very short, with only six learning units; therefore, one could not regard it as being satisfactory, even though the amount of potentially significant terrain analysis content was 50 per cent. After all, a squadron commander is supposed to have optimal knowledge and skills in terrain analysis.

Therefore, from the data, it was evident that some degree of terrain analysis did exist in the course curricula and contributed to the SA Army's goal of developing leaders who are competent in terrain analysis, but only to a certain level - the measurement of which fell outside the scope of this research.

\section{Conclusions}

In conclusion, the findings for the Corps Training Course (701 ENGR 006), the Troop Commanders Course (701 ENGR 16) and the Squadron Commanders Course (701 ENGR 17) were nearly identical. However, those for the Troop Officers Course (701 ENGR 103) differed in that it was an excellent programme. This latter course consisted of some of the best lessons for terrain analysis and it was also the most complete package for educating learners on terrain analysis.

The greatest shortfall found in all four courses was the lack of assessment instruments that were tied directly to terrain analysis learning objectives. This is critical, because terrain analysis is the learning objective that "describes the competency or performance expected of an officer as a result of the educational experience and the learning level expected to be accomplished". ${ }^{62}$ Correcting the assessment shortfalls in terms of learning objectives in the curriculum would lead to better competency in terrain analysis planning and execution. Learners' understanding of the curriculum content for terrain analysis remained unknown due to the use of assessments that did not properly measure individual learning. As a result, the contribution of the total curriculum to the SA Army's goal of developing leaders who were competent in terrain analysis is also unknown.

The Corps Training Course (701 ENGR 006), the Troop Officers Course (701 ENGR 103), the Troop Commanders Course (701 ENGR 16) and the Squadron Commanders Course (701 ENGR 17) as presented by the South African Army School of Engineers should contribute to the SA Army's goal of developing leaders who are competent in terrain analysis. This is only because the curriculum serves to introduce and expose the learner to terrain analysis. It is the level or depth of 
competency (whether the learner actually achieved the learning objective) that remains unknown.

Three facts support this conclusion. First, the mix of curricula for officers' occupational courses. The four separate learning experiences and perhaps different competency results produced an inconsistency. The disconnect between the units' teaching branches should be corrected to establish consistency in the terrain analysis content presented by the South African Army School of Engineers. Second, the curriculum did not account for all terrain analysis tasks found in the literature review. Third and last, regardless of which terrain analysis content was presented during the year, the individual assessment instruments used to measure learning were poor and the percentage grades awarded for group work or class participation too high.

The conclusions suggest the following recommendations. Terrain analysis should be included in the Corps Training Course curriculum as a foundation for all members entering the engineer corps. This will serve as a solid base and the lowest support of a terrain analysis development structure for all officers of the Engineer Corps. If this could be done all officers would have a basic knowledge of terrain analysis that could be carried through to other courses, which would add to and improve this basic knowledge. For example, the Troop Officers Course was by far the best in-house model (as far as subject content is concerned), with approximately 41 per cent of the content being significant to the research. Thus, if terrain analysis were added to the Corps Training Course as a lesson on its own, it would equip officers with the knowledge to understand more of the tasks of terrain analysis as they progress through their careers in the Engineer Corps. This programme change would ensure universal exposure to terrain analysis in the Corps for all army engineer officers. The Troop Commanders course and Squadron Commanders course curricula should also be considered in terms of adding more terrain analysis content in order to equip officers with the necessary terrain analysis knowledge and skills as they progress through the ranks in order to be able to perform the different tasks expected of a terrain analyst. The actual lesson content and programme synchronisation are subjects recommended for further study.

The South African Army School of Engineers has a responsibility to the South African Army to keep abreast of this content-integration process. In other words, if one course already has Obstacle and Concealment as a lesson, it should not be repeated in other courses, in order to allow for more tasks on terrain analysis to be added. Course content should be organised according to seniority, i.e. rank-wise, because officers are given responsibilities according to their ranks. Different rank groups perform different tasks according to their level of competency. Thus, integrating terrain analysis education sequentially in all four courses would allow learners to adjust to the progression of the levels of their occupation. Textbooks and articles on terrain analysis should be used for additional information in order to keep up with the latest trends in terrain analysis. 
At the time of the research, the South African Army School of Engineers officers' occupational course curricula did not account for the terrain analysis tasks of visualisation and analysis development. As a final recommendation to advance terrain visualisation and analysis development, lessons in the courses at the South African Army School of Engineers should be formally aligned with the South African Army Engineer Terrain Intelligence requirements. If this is done, the school would be informed about all the important tasks of terrain analysis that officers should be taught.

To improve terrain analysis abilities, exercises are needed during the occupational courses that require officers to evaluate the impact of terrain on operations. This would serve as an important assessment instrument that would improve the development and experience of officers, as opposed to just earning grades for theory. Officers need to gain an appreciation for the space, time and distance relationships that are affected by different environments when solving tactical problems. This might require more tactical and terrain exercises. The resident South African Army School of Engineers officers' occupational courses are designed to ensure that all officers' branches are represented. With this comes the collective expertise of the Army. There may be value in sharing understanding of terrain amongst officers during well-planned tactical exercises.

The research suggests that the Corps Training Course (701 ENGR 006), the Troop Officers Course (701 ENGR 103), the Troop Commanders Course (701 ENGR 16) and the Squadron Commanders Course (701 ENGR 17), as presented by the South African Army School of Engineers do contribute to the SA Army's goal of developing leaders who are competent in terrain analysis. However, it was also found that the courses might not be offering enough terrain analysis content to the officers. Furthermore, the assessment instruments for the courses were found to be less than satisfactory for the assessment of individual competence.

\section{Endnotes}

${ }^{1}$ Treleaven, DL. "We're all terrain experts". Engineer. February 1995. 8.

${ }^{2}$ Sun-Tzu. The art of war. Translated by RD Sawyer. Boulder, CO: Westview Press, 1994, 140.

${ }^{3}$ Collins, J. Military geography for professionals and the public. Washington, DC: National Defense University Press, 1998, 404.

${ }^{4}$ Galgano, FA. Military science for the non-professional. In Galgano, FA \& Palka, EJ (eds), Modern military geography, New York: Routledge, 2011, 23.

${ }^{5}$ South African National Defence Force. The SA Corps of Engineers. Pretoria: SA Army College, 1997, 2.

${ }^{6}$ Orava, E. "Military terrain analysis". Master's thesis. Helsinki University of Technology, 1999.

${ }^{7}$ Arnold, E. "Being a terrain visualization expert". Engineer. March 1997. 22. 
${ }^{8}$ Aadland, AB \& James, A. "Engineer White Paper: Into the objective force". Engineer. April 2002. 8.

${ }^{9}$ US Department of the Army. FM 5-10. Combat Engineer Platoon. 1995. 1-2.

${ }^{10}$ US Department of the Army. FM 5-100. Engineer operations. 1996. 3-8.

${ }^{11}$ US Department of the Army. FM 17-95. Cavalry operations. 1996. 1-2.

${ }^{12}$ US Department of the Army. FM 90-13. River crossing operations. 2000. 1-2.

${ }^{13}$ FM 3-34.230, 2000, 1-3.

${ }^{14}$ Stevens, RW. Interview with Maj. S Tupper, Deputy Director TPIO-TD, USA. In "Enabling engineer officers as terrain experts". Master's thesis. Command and General Staff College, Fort Leavenworth, 2003.

15 Ibid.

${ }^{16}$ Ibid., p. 79.

${ }^{17}$ Department of the Army Headquarters. FM 5-33. Terrain analysis. Washington, DC, 1990.

18 Ibid.

${ }^{19}$ Kiszely, J. "Post-modern challenges for modern warriors". Shrivenham Paper no. 5. Swinton: Defence Academy of the United Kingdom, 2007.

${ }^{20}$ Institutional training takes place in military and/or civilian institutions.

${ }^{21}$ Self-development may be through distance learning, professional reading or individual study.

${ }^{22}$ Guttieri, K. "Professional military education in democracies". In Bruneau, TC \& Tollefson, SD (eds), Who guards the guardians and how? Democratic civilmilitary relations, Austin: University of Texas Press, 2006, 318-319.

${ }^{23}$ Stephens, MD (ed). The educating of armies. New York: St Martin's Press, 1989.

${ }^{24}$ Esterhuyse, AJ. "Strategy, operational art and tactics: Who is responsible for what in the SANDF?" African Armed Forces Journal. 2000. 32.

${ }^{25}$ Arnold op. cit., pp. 22-23.

${ }^{26}$ Clausewitz, C. On war. Edited and translated by M Howard \& P Paret. Princeton, NJ: Princeton University Press, 1984, 348-360.

${ }^{27}$ School of Engineers. Curriculum for the course: Corps training, 701 ENGR 006. 2008.

${ }^{28}$ School of Engineers. Draft curriculum for the Course: Troop Officers, 701 ENGR 103. 2008.

${ }^{29}$ School of Engineers. Curriculum for the Course: Troop Commanders, 701 ENGR 16. 2011.

${ }^{30}$ School of Engineers. Curriculum for the course: Squadron commanders, 701 ENGR 17. 2008. 
${ }^{31}$ Rosengren, KE. “Advances in Scandinavia content analysis: An introduction”. In Rosengren, KE (ed), Advances in content analysis, Beverly Hills, CA: Sage, 1981, 9-19.

${ }^{32}$ Barcus, FE. "Communications content: Analysis of the research 1900-1958 (A content analysis of content analysis)". Doctoral dissertation. University of Illinois, 1959.

${ }^{33}$ Berelson, B. Content analysis in communication research. Glencoe, IL: Free Press, 1952.

${ }^{34}$ Morgan, DL. "Qualitative content analysis: A guide to paths not taken". Qualitative Health Research 3. 1993. 112-121.

${ }^{35}$ Nandy, BR \& Sarvela, PD. "Content analysis reexamined: A relevant research method for health education". American Journal of Health Behavior. 21. 1997. 222-234.

${ }^{36}$ Weber, RP. Basic content analysis. Beverly Hills, CA: Sage, 1990.

${ }^{37}$ Downe-Wamboldt, B. "Content analysis: Method, applications, and issues". Health Care for Women International. 1992. 13, 314.

${ }^{38}$ Hsieh, HF \& Shannon, SE. "Three approaches to qualitative content analysis". Qualitative Health Research 15/9. 2005. 1277-1288.

${ }^{39}$ Weber op. cit.

${ }^{40}$ Tesch, R. Qualitative research: Analysis types and software tools. Bristol, PA:

Falmer, 1990.

${ }^{41}$ Hsieh \& Shannon op. cit.

${ }^{42}$ Hsieh \& Shannon op. cit.

${ }^{43}$ School of Engineers, 2008 op. cit.

${ }^{44}$ School of Engineers, 2008b op. cit.

${ }^{45}$ School of Engineers, 2011 op. cit.

${ }^{46}$ School of Engineers, 2008c op. cit.

${ }^{47}$ School of Engineers, 2008 op. cit., p. 1.

${ }^{48}$ School of Engineers, 2008b op. cit., p. 2.

${ }^{49}$ School of Engineers, 2011 op. cit., p. 2.

${ }^{50}$ School of Engineers, 2008c op. cit., p. 1

${ }^{51}$ Ibid., p. 2.

${ }^{52}$ South African National Defence Force. Directorate Language Service. Terminology Service. Joint Military Dictionary. SA Weermag, 1983, 85.

53 Ibid., p. 219.

${ }^{54}$ Ibid., p. 250.

55 Ibid., p. 297. 
${ }^{56}$ Oxford University Press. Unabridged Oxford English Dictionary, Oxford, Oxford University Press, 2002, 939.

${ }^{57}$ Department of Defense. Dictionary of Military and Associated Terms. 2010. As amended 15 September 2011.

58 Ibid.

${ }^{59}$ South African National Defence Force op. cit., p. 368.

${ }^{60}$ Department of Defense op. cit.

${ }^{61}$ South African National Defence Force op. cit., p. 368.

${ }^{62}$ Command and General Staff School, Unpublished document, 2006, 31. 